\title{
Gender Disparities in Drivers of Workers Satisfaction
}

\author{
Fapohunda, Tinuke. M \\ Department of Industrial Relations and Public Administration Lagos State University Lagos. Nigeria
}

\begin{abstract}
The relationship between workers job satisfaction and gender has been examined frequently. However, the results of many of the studies have been contradictory. Some studies have shown females to be more satisfied than men whereas other studies have shown men to be more satisfied than female. However most of the researches in this area report no significant differences between the sexes in relation to job satisfaction. This study analyses gender differences in the key drivers of job satisfaction among a sample of print media journalists in Lagos. Nigeria. Eight drivers of differences in levels of job satisfaction were investigated. Data was collected from two hundred and fifty (250) journalists from the five print media houses selected for the study. The simple random sampling was used to select the 50 respondents from each organization. Using constructs from literature and items from tested scales a questionnaire was developed for the study. Of the 250 questionnaires administered only 236 were returned in useable conditions. The respondents were made up of, $44 \%$ female (104), and 56\% male (132). Eight independent variables of workers satisfaction namely stability and security; feedback; performance measures; instrumentality; contingent rewards; motivation; control as well as autonomy and challenge were tested and found to be significantly and positively correlated with workers job satisfaction for both females and males. The results indicate that there are no differences in the drivers of workers satisfaction between genders.
\end{abstract}

Keywords: disparities, drivers, gender, workers, satisfaction.

\section{Introduction}

For any organization to be successful the satisfaction of their employees must be continuously ensured. Job satisfaction has to do with an individual's reaction to the job experience. It is how content an individual is with his or her job. Several variables are considered to be vital to job satisfaction because they all influence the way a person feels about their job. Such variables include: pay, promotion, benefits, supervisor, co-workers, work conditions, communication, safety, productivity, and the work itself. Each of them figures differently in an individual's job satisfaction. Workers satisfaction is a crucial aspect of an organization's prosperity and goal attainment. It constitutes an important issue for management and workers in any organizational setting.

Gender is one of the universal dimensions on which status differences are based. It is a social construct specifying the socially, culturally prescribed roles that males and female are to follow. It involves those social, cultural and physiological aspects linked to males and females through particular social contexts. In the last couple of decades there has been increased interest in exploring factors influencing workers satisfaction with a specific focus on gender differences. For instance Clark (1997)[1] in testing the idea that men and female in identical situations should be equally satisfied found that the average for females was lower in stature and income than for males, even though females reported higher levels of satisfaction. Medaiyese (2002)[2] found that workers satisfaction declines with increasing levels of education and argues that higher levels of education tend to increase workers goal and income expectations. Adenekan (2005) [3]reports from a study in Kenya that males and females working in gender-balanced groups have higher levels of satisfaction than those working in homogeneous groups. Fields \& Blum (1997) [4]affirms that workers who work in groups comprised of mostly males tend to show the lowest levels of workers satisfaction. Pook, Füstös, and Marian (2003) [5] examined the effect of gender bias on satisfaction in a survey in Eastern Europe and reports that females are less likely to receive help from their managers toward advancement and that they are less satisfied than men with the work they perform as a result of being assigned less-challenging tasks, non-commensurate with their backgrounds. However, Oloko (2001)[6] reports that overall females have higher satisfaction than men and have even higher satisfaction in workplaces dominated by females. Oloko adds that males and females value flexibility differently, and once this difference is controlled for, gender composition in the workplace plays no role in determining satisfaction of female. This study examines differences in drivers of workers satisfaction due to gender for journalists in the print media in Nigeria.

Previous studies in this area have looked at differences in workers satisfaction due to gender in various settings, and the results have differed. This study examines differentials in drivers of workers satisfaction arising from gender using the print media in Nigeria as a unit of analysis. Specifically, the study examines independent variables that have been correlated with workers job satisfaction and also the extent to which these drivers differ between male and female print media journalists in Nigeria being a male oriented profession where females find it harder to get into and remain than males. 


\subsection{Gender}

\section{Literature Review}

Females have always had a lower status than males, though the extent of the gap between them varies across cultures, and time. Gender affects and often determines the roles that females play in social institutions, society and their occupations are no exception. Moser (2010) [7] affirms that gender is the difference between males and females within the same household and within and between socially and culturally construed changes over time. These differences are often in responsibilities, access to resources, contracts, opportunities, needs, perception and views. The issue of gender goes beyond possession of the subjective sense of male or female behaviours that are considered normal and appropriate for sex differentials. As ascribed by the society, gender roles lead to assumptions about how people will behave and once these assumptions are widely accepted, they begin to function as stereotypes. Females are in general conditioned by societal and cultural pressures to adopt certain ideal behavioural patterns constant with the society's expectations of how they must behave. It is believed in the Nigerian cultural set up that males are the ones who should have the dominant and aggressive qualities while the females must exhibit passive and dependent qualities. This belief has so permeated the society that any female that exhibits the set roles for males is regarded as a deviant and ill-brought up person. In present day Nigeria the situation and the society is rapidly changing. One of the most remarkable changes in the emancipation of female has to do with their emergence from the seclusion of their homes into business activities outside their homes.

\subsection{Gender Differences in the Workplace}

Across all societies known to mankind, work has always occupied prime place in people's lives. However, the roles of female and males are usually defined in different cultures. Be it traditional societies or the so called developed societies, females have been seen as care-givers, mothers and wives with the primary function of child rearing and taking care of the 'domestic' affairs. On the other hand, males are saddled with resounding functions of political, economic and military activities that require valour. Giddens (2006)[8] observes that there has never been any known society where females were more powerful than males. In the Nigerian context, the males have always taken the lead, although that is not to say that females have not made their mark in some circles; either in pre-colonial or post-colonial times. In traditional societies, the males hunted for games, while the females gathered fruits and coordinated other domestic affairs at the home front, including reproductive functions. The advent of modern capitalism, which moved production activities to the factory and pushed man away from the farm to paid employment, further reinforced the male's dominant position in both economic and power relations. This dominant position is usually referred to as patriarchy.

Men's revered position of dominance over the years has been challenged owing to widespread agitations for equality of gender by feminist movement's clamouring for change in status quo. The idea of the female's place being in the kitchen is changing gradually and occupations like nursing, which was regarded as the female's domain has been witnessing the influx of the male folk. Though globally, the ratio of male to female in the labour force is getting increasing, Soetan (2002) [9]in an analysis of various sectors in Nigeria shows that men are more in the labour force with virtually all sectors dominated by men. Again, females are concentrated in agricultural, wholesale, and retail trade sectors, where they are mostly in the categories of selfemployed (36.4\%) and unpaid family workers (46.2\%). The high representation of female workers in limited echelons of the public sector, but their virtual absence in the middle and low-level occupations in the private wage sector is in keeping with gender-based occupational segregation trends. The United Nations Development Programme (UNDP)[10], in its 2005 Human Development Report observes that female's labour force participation rose by just 4 percent in 20 years (from 36 percent in 1980 to 40 percent in 2000). The UNDP report adds that in 55 countries with comparable data, the average female wage is three quarters $(3 / 4)$ of the male wage in the non-agricultural sector. In developing countries, females still constitute less than one-seventh $\left({ }^{1} / 7\right)$ of administrators and managers. Females occupy only 10 percent of parliamentary seats and only 6 percent of cabinet positions. Females in the labour force have been increasing in numbers over the past few decades with more and more moving into paid work. Females have also made considerable relative increases compared to men in school and university enrolment, graduate and professional education and in entering management and professional occupations.

Females making inroads into the labour force is as a result of myriad of factors such as the changes in their domestic roles, monumental decline in the rate of child birth and increase in the age at which modern females give birth to children. Also the feminist agitation for gender equality and female empowerment has helped to create awareness that has motivated females to take up jobs in industrial organisations, which were stereotyped as men's. Financial pressure is another push factor that gingered females into paid work. As a result of the high rate of unemployment of males, females are directly or indirectly forced to work to cater of the family. Also in a situation where the man's income cannot support the family life style the need for double pay becomes a way out. Another driving factor for females into the labour force or paid work is the need for 
personal fulfilment. In addition, formal education has helped to reduce the gap between the male and female in the workplace. Females with requisite qualifications are now found in top management positions and boards of companies either in the private sector or in the public sector though their number is still relatively few compared with the males.

The consequence of these is that the status of females has improved. Females nowadays aspire for positions of authority in the workplace. They now have a voice in the workplace, even in jobs perceived to be the man's work. It is however important to note here that the female's responsibility for house work and child care affects the types of jobs many they prefer, since flexibility (in terms of hours and relatively easy entry exist/re-entry) enable them to combine work and family responsibilities more easily. Females tend to gravitate towards occupations where either because of their preferences and characteristics and/or because employers prefer to employ female in these occupations. Economic theories explain that it could be that occupations become "female" because of sex stereotyping. New-classical economic/human capital theory holds that preferences of female and employers are responsible for the concentration of female in flexible occupations. While family responsibilities can be expected to increase female preferences for flexibility occupations, the stereotyping of certain work can also be expected to affect the type of occupations opened to them.

Gender differences in the workplace typically stem from social factors, which influence the behaviors of men and female. Some organizations welcome gender diversity and encourage the inclusion of both sexes when making company decisions and offering promotional opportunities. Other organizations discourage gender inclusion and promote bias in the workplace. With most companies, gender differences add value and varying perspectives to an organization. Deaux and Enswiller (2003)[11] in their survey of tasks perceived as male appropriate discovered that a good performance by a male is attributed to skill while the same performance by a female was seen to be the result of chance. Also good performance by the male was attributed to general intelligence, as female were constituted to be less intelligent than men and highly dependent on men. Independent of the task, man was rated as more skilful than females.

\subsection{Job Satisfaction}

Locke (1976) [12] defines job satisfaction as a pleasurable or positive emotional state resulting from the appraisal of one's job or job experiences. Job satisfaction is an affective or emotional response toward various facets of one's job and it has been a topic of great interest to researchers and practitioners in a wide range of fields, including organizational psychology, public administration, and human resource management. Job satisfaction is important because of its implications for job -related variables. Results of studies such as (Judge et al (2001)[13] Colbert and Heller(2001)[14], Awe (2006) [15]and Majekodunmi (2008)[16] indicate that job satisfaction is positively correlated with motivation, involvement, organizational citizenship behaviour, organizational commitment, life satisfaction, mental health, and performance, and negatively related to absenteeism, turnover, and perceived stress. Smith, Kendall, and Hulin (1989) [17] considered five facets of job satisfaction: pay, promotions, co-workers, supervision, and the work itself. Spector (1995)[18] assessed nine facets: pay, promotion, supervision, fringe benefits, contingent rewards, operating conditions, co-workers, nature of work, and communication. Job satisfaction can also be seen within the broader context of the range of issues which affect an individual's experience of work, or their quality of working life. It can be understood in terms of its relationships with other key factors, such as general well-being, stress at work, control at work, home-work interface, and working conditions.

Many theories have been proposed concerning the causes of workers' job satisfaction. Judge et al (2001) [13]classifies them into three categories: situational theories, dispositional approaches, and interactive theories. Situational theories assume that satisfaction results from the nature of one's job or other aspects of the environment; examples are Herzberg's (1967) two-factor theory, the social information processing approach, and the characteristics model. Dispositional approaches suggest that satisfaction is rooted in the personal makeup of the individual. Interactive theories propose that satisfaction results from the interplay of the situation and personality; examples are the Cornell integrative model and the value percept theory. Although one can assume that these theories are competing or incompatible explanations of satisfaction, Judge et al. (2001)[13] suggests that some may be compatible with each other.

One of the biggest preludes to the study of job satisfaction was the Hawthorne studies. These studies (1924-1933), primarily credited to Elton Mayo of the Harvard Business School, sought to find the effects of various conditions (most notably illumination) on workers' productivity. These studies ultimately showed that novel changes in work conditions temporarily increase productivity (called the Hawthorne Effect). It was later found that this increase resulted, not from the new conditions, but from the knowledge of being observed. These findings provided strong evidence that people work for purposes other than pay, which paved the way for researchers to investigate other factors in job satisfaction. 


\subsection{Gender and Job Satisfaction}

The relationship between workers job satisfaction and gender has been examined frequently. However, the results of many of the studies have been contradictory. Some studies have shown females to be more satisfied than men whereas other studies have shown men to be more satisfied than female. Ogundele (2005) [19] observes however, that most of the researches in this area report no significant differences between the sexes in relation to satisfaction. Kim and Cho (2003) [20] affirm that satisfaction with work is the most influential determinant of the quality of life among government workers in Korea. As regards to what males and females look for in a job, the evidence is also inconsistent. Intrinsic and extrinsic work orientations represent work-related preferences to value specific types of rewards inherent in the work environment. Individuals high in intrinsic orientation value opportunities for satisfaction with the work itself, feelings of self-determination and competence, and personal development, whereas individuals high in extrinsic orientations primarily value financial compensation, promotion, and prestige. Some studies show that females value extrinsic characteristics more than do men, and some show the opposite. Yet others have found no differences between men and female in terms of intrinsic and extrinsic work orientations. According to Mottaz (1986)[21], at lower work levels males focus on intrinsic and extrinsic rewards and have more intrinsic work-related values, whereas females emphasize social rewards and more relationship-oriented work-related values. However, at managerial levels, males and females tend to view their jobs as being equally rewarding and have similar work-related values. Kim, (2005)[22] examined gender differences in orientation to work, using closely comparable data collected in nine Western European countries. The results show that males place greater value than females on both extrinsic and intrinsic work values and are somewhat more satisfied than females with their jobs.

A central paradox in studies of gender and job satisfaction is why female's satisfaction is not lower than men's, given that female's $s$ are often inferior in terms of pay, autonomy, and promotional opportunity. Sousa-Poza and Sosa-Poza (2000) [23]shows that in most countries females are actually less satisfied than men, whereas in the Great Britain and the United States females had much higher satisfaction levels than men among the 21 countries employed for the study. Kim (2005) [22] thus suggests that the gender/-satisfaction paradox is not a worldwide but may be an Anglo-Saxon phenomenon. Khaleque and Rahman (1987) [24] found that there were significant differences between some demographic variables (age, experience, social status) and workers satisfaction in Bangladesh. Older workers and married females were more satisfied with their jobs than other workers were.

This study examines the paradox by seeking to find how the job satisfaction of female journalists in the print media in Nigeria compares with that of male workers. The study tests for both females and males eight variables which have been positively correlated with workers satisfaction. The independent variables are (i) performance measures (ii) stability and security (iii) feedback (iv) instrumentality (v) contingent rewards (vi) motivation, (vii) control and autonomy (viii) challenge

(i) Performance Measures

Performance has to do with the outcomes of work. The critical factors that determine performance include individual attributes, organizational support, work efforts and the work environment. Performance measures drive the actions of workers and are used to establish standards to define expectations and to track accomplishments. Performance measures also motivate workers to implement, plan, and achieve specific goals. It requires a management style that is open and honest and encourages two-way communication between superiors and subordinates. It requires continuous feedback. Sirota and Mischkind (2006)[25] emphasize that comments concerning improvements should be specific, factual, unemotional, and directed at performance rather than at workers personally. Arising from the foregoing is the first hypothesis for the study that

$\mathrm{H}_{1}$ : There is a positive and significant correlation between performance measures and workers satisfaction.

(ii) Stability and Security

Bolt (1983) [26] reports that workers who feel secure in their jobs are more productive than those who do not.

Sirota and Mischkind (2006) [25] identifies three sets of goals that the great majority of workers seek from their jobs. The first is equity, which has to do with respecting and treating workers fairly in areas such as pay, benefits and security. The second is achievement, which involves being proud of one's job, accomplishments, and employer. The third has to do with camaraderie, which embraces good, productive relationships with fellow workers. Sirota \&Mischkind add that of the three, the most basic goal is to provide workers with a sense of security in an environment in which they do not fear that their jobs are at risk where their performance is not perfect and where layoffs are considered an extreme last resort and not just another option for dealing with hard times. This informed the second hypothesis that

$\mathrm{H}_{2}$ : Stability and security has a positive and significant correlation with workers satisfaction.

(iii) Feedback

Providing workers with feedback on performance keeps task-directed behavior on track and stimulates workers to exert greater effort. Feedback fulfills a need for information on the extent to which personal goals are 
met and as a point of social comparison about an individual's relative performance. Feedback loops enable the experiences and knowledge gained on the job by individuals to modify corporate objectives. It can have significant and positive effects on performance when it is provided for a familiar task, is directed on goal setting, and does not direct attention to the self. Kim (1984) [27] affirms that goal setting and feedback results in improved workers performance. Based on a survey of 112 workers of a non-profit service organization, Jawahar (2006) [28]reports that appraisal feedback is positively related to workers satisfaction and organizational commitment and that workers satisfaction with feedback is positively related to workers satisfaction and also influences future performance. This study therefore proposes a third hypothesis that

$\mathrm{H}_{3}$ : Feedback on performance is positively and significantly correlated with workers satisfaction.

(iv) Instrumentality

Walker, Churchill and Ford (1977) [29]groups workers satisfaction, into intrinsic and extrinsic dimensions. While intrinsic satisfaction is related to the internal rewards such as satisfaction with work itself and with opportunities for personal growth and accomplishment, extrinsic satisfaction refers to rewards bestowed on workers such as pay, organization support, and opportunities for promotion, among others. The importance of a worker's role in society is also a source of personal satisfaction. Workers motivation is therefore a function of expectancy, instrumentality, and valence of rewards. Instrumentality is the individual's estimate of the probability that achieving an improved level of performance will lead to increased attainment of a particular reward. Teas(1981)[30] finds that workers -specific self-esteem and internal control orientation are positively related to instrumentality perceptions. This study therefore proposes the hypothesis that

$\mathrm{H}_{4}$ : There is a positive and significant correlation between instrumentality and workers satisfaction.

(v) Contingent rewards

Satisfaction is related to contingent rewards. Contingent rewards constitute a major factor in attracting industrials to an organization, persuading them to remain and inducing them to contribute positively to the achievement of corporate goals. It is also important in building workers loyalty and commitment to the employer, increasing satisfaction and reducing turnover, absenteeism, complaints and grievances. Awe (2006) [15]asserts that employers who use money to motivate workers may find that the overall response from both men and female is nearly the same. Awe adds that raises, bonuses and other monetary rewards may only be a short-term motivator for both genders. While a worker's motivation may rise for a brief time after he receives a pay increase, workers often increase their spending after receiving a raise, which consumes their additional pay. That potentially lowers their motivation to its previous level because their financial situation remains unchanged. This study proposes that

$\mathrm{H}_{5}$ : There is a positive and significant correlation between contingent rewards and workers' satisfaction.

(vi) Motivation

Motivation is the drive and stimulation which enables individuals to perform their work. Michael (2005)[31] sees motivation as the act of stimulating someone or oneself to get a desired course of action, to push the right button, to get a desired reaction. It involves a process of creating organizational conditions which will impel workers to strive to attain company goals. Motivation is vital to successful business performance.

McCleland (1965)[32] in a study which focused on socially acquired motives argues that satisfaction is important because people tend to act in a way that will critically affect the performance of their jobs and tasks. Drucker (2000) [33]in a study of some industrial workers observed that a worker is more productive, the more thoroughly his work is set up and laid out for him. This implies that a worker will be more productive and efficient the more his work is well designed and laid out. Motivational factors include pay on performance which could also be referred to as productivity bonus or profit sharing, security, good medical services, better conditions of services, praise, recognition in the form of special awards or promotion, provision of staff buses and canteen services to mention but a few. It is not always clear whether certain things motivate male and female workers differently. For example, money and other financial rewards potentially have the same effect on both genders, according to some workplace studies. Nonetheless, motivational differences may appear among men and female based on how employers handle the objects of motivation. This study hypothesizes that $\mathrm{H}_{6}$ : There is a positive and significant correlation between motivation and workers satisfaction.

\section{(vii) Control and Autonomy}

Satisfaction is related to expectations. The expectancy model of Lawler and Stuttle's (1983)[34] proposes that workers motivation is a function of the perceived likelihood of a successful accomplishment and that such accomplishment will result in securing certain outcomes or rewards. Positive rewards can influence satisfaction. Results from the study of Collins (2006)[35] suggest that positive leader rewards have a positive effect on influencing workers job satisfaction. Okafor (1997) [36] reports a positive relationship between 
workers internal control orientation and motivation. Kimberly (2003)[37] found that goal clarity, planning, autonomy, and participation in goal setting are factors positively related to job satisfaction. Workers often view having the power to make decisions that affect their own work as most important employment attribute. This study postulates that

$\mathrm{H}_{7}$ : Workers control and autonomy has a positive and significant correlation with workers satisfaction.

(viii) Challenge

Workers challenge may be external or internal in nature. While the external may include positional requirements, formally prescribed tasks, and expectations and demands from others, the internal pressures result from individual values, needs, abilities, past experiences, cognitive style, and other idiosyncratic characteristics. Challenging tasks generate pressure on individuals to prove their competence to do high-quality work and contribute to organizational goals, which ultimately results in satisfaction. Locke (1976)[12] suggests that challenging goals result in higher levels of workers performance than easy-to-accomplish goals. Again, specific challenging tasks result in a higher level of performance than non-specific goals. Difficult tasks that are perceived as challenging-rather than impossible to achieve constitute an important element in satisfying workers. Arising from this the study hypothesizes that

$\mathrm{H}_{8}$ : Challenge has a positive and significant correlation with workers satisfaction.

\section{Theoretical Framework}

Many theorists have tried to come up with an explanation for why people feel the way they do as regards their job. Some of the theories include:

3.1 The Discrepancy Theory - The discrepancy theory explains the ultimate source of anxiety and dejection. This theory posits that all individuals will learn what their obligations and responsibilities are for a particular function, over a time period, and if they fail to fulfil those obligations then they are punished. Agitation, anxiety dejection, disappointment, or even depression is the main response when an individual fails. If achievement of the obligations is obtained then the reward can be praise, approval, or love.

3.2 The Affect theory- The theory states that job satisfaction comes from what a person feels is important not the fulfillment or non-fulfillment of their needs. The main thrust of the theory is that satisfaction is determined by a discrepancy between what one wants in a job and what one has in a job. The theory opines that the extent to which a person values a facet of work consequently determines how satisfied or dissatisfied the person becomes when expectations are either met or are not met.

3.3 The Dispositional theory- This dispositional theory is a very general theory that suggests that people have innate dispositions that cause them to have tendencies toward a certain level of satisfaction, regardless of their jobs. Judge et al. however proposed the Core Self-evaluations Model which narrowed the scope of the dispositional theory. The core self-evaluation model suggests that there are four core self-evaluations that determine one's disposition towards job satisfaction namely : self-esteem, general self-efficacy, locus of control, and neuroticism. Higher levels of self-esteem and general self-efficacy lead to higher work satisfaction, internal locus of control leads to higher job satisfaction and lower levels of neuroticism lead to higher job satisfaction.

3.4 Opponent process theory- This theory suggests that the primary reaction (the immediate emotional response) combined with the secondary reaction (the later emotional response) creates a stabilized equilibrium which results in job satisfaction. A person's job satisfaction includes the rewards for doing the job and performing it well. These rewards range from an improved work environment to higher security and more responsibility. Organizational commitment is also a result of job satisfaction. While the positive indicators of commitment are productivity and health, the negative indicators include absenteeism, sabotage, and violence and they also indicate low job satisfaction.

\subsection{Lawler's Theory-}

Lawler posits that job satisfaction is driven by a motivational framework. This idea deals with how a person measures job satisfaction based on what they get compared with what they feel they deserved. Satisfaction is determined by the difference between what a person receives and what they expect. Therefore, dissatisfaction occurs when a person receives less or more than what was expected.

3.6 The Two-Factor Theory- This theory which was developed by Hertzberg states that certain factors in the workplace called 'hygiene or maintenance factors' cause job satisfaction, while a separate set of factors called 'motivators' or satisfiers' cause dissatisfaction. 'Hygiene or maintenance factors' like achievement, recognition, the work itself, advancement and growth on the job result in job satisfaction while 'motivators' or satisfiers' 
factors like company policy, supervision, relationship with boss, work conditions, salary, relationship with peers and securitybring about dissatisfaction. The theory suggests that satisfaction and dissatisfaction at work nearly always arose from different factors, are not simply opposing reactions to the same factors, as had always previously been believed. The opposite of satisfaction is not dissatisfaction, but rather, no satisfaction. Similarly, the opposite of dissatisfaction is no dissatisfaction. Herzberg suggests that management should improve the 'hygiene factors' which affect the environment or context of the job in order to prevent job dissatisfaction and that motivators should be included in the job in order to increase job satisfaction.

3.7 The Equity theory- This theory shows how a person views fairness with regard to social relationships. During a social exchange, a person identifies the amount of input compared to the output, as well as how much effort another person puts forth. A perception of inequality between two social groups or individuals, results in distress because the ratio between the input and the output are not equal.

\subsection{The Job Characteristics Model}

This model proposed by Hackman \& Oldham states that there are five core job characteristics : skill variety, task identity, task significance, autonomy, and feedback which impact three critical psychological states: experienced meaningfulness, experienced responsibility for outcomes, and knowledge of the actual results, in turn influencing work outcomes like job satisfaction, absenteeism, and work motivation.

\section{Hypotheses}

The hypotheses tested in this study are summarised as follows:

$\mathrm{H}_{1}$ : There is a positive and significant correlation between performance measures and workers satisfaction.

$\mathrm{H}_{2}$ : Stability and security has a positive and significant correlation with workers satisfaction.

$\mathrm{H}_{3}$ : Feedback on performance is positively and significantly correlated with workers satisfaction.

$\mathrm{H}_{4}$ : There is a positive and significant correlation between instrumentality and workers' satisfaction.

$\mathrm{H}_{5}$ : There is a positive and significant correlation between contingent rewards and workers' satisfaction.

$\mathrm{H}_{6}$ : There is a positive and significant correlation between motivation and workers' satisfaction.

$\mathrm{H}_{7}$ : Workers control and autonomy has a positive and significant correlation with workers' satisfaction.

$\mathrm{H}_{8}$ : Challenge has a positive and significant correlation with workers' satisfaction.

\section{Research Methodology:}

The population for the study is 879 comprising of the entire male and female staff of the four selected print media houses namely The Guardian, The Punch and Business Day and the Nigerian Tribune newspapers. The sample size for the study is put at two hundred and fifty (250) workers. Fifty (50) workers each were sampled from the five media houses. The simple random sampling was used to select the respondents from each organization. Using constructs from literature and items from tested scales a questionnaire was developed for the study. Of the 250 questionnaires administered only 236 were returned in useable conditions. The respondents were made up of, $44 \%$ female (104), and 56\% male (132).

\section{Test of Hypotheses}

Statistical tests were performed to test the hypotheses formulated. Summated scales of construct items were calculated for both females and males it was then used to test workers satisfaction relationships using Pearson bivariate correlation. The results are presented in Table 1 for the dependent variable (workers satisfaction) and the independent variables for female and male respondents. Results indicate highly significant positive correlations $(\alpha<0.001)$ between all independent variables constructs and workers satisfaction for both genders.

Table 1. Workers Satisfaction and Independent Variables

\begin{tabular}{|c|c|c|c|c|c|c|c|c|}
\hline \multirow[b]{2}{*}{$\begin{array}{l}\text { Workers } \\
\text { Satisfact } \\
\text { ion and }\end{array}$} & \multicolumn{6}{|c|}{ Independent Variables } & \multirow[b]{2}{*}{$\begin{array}{l}\text { Control } \\
\text { and } \\
\text { Autono } \\
\text { my }\end{array}$} & \multirow[b]{2}{*}{ Challenge } \\
\hline & $\begin{array}{l}\text { Stabilit } \\
\text { y } \\
\text { and } \\
\text { Securit } \\
\text { y }\end{array}$ & $\begin{array}{c}\text { Feedba } \\
\text { ck }\end{array}$ & $\begin{array}{l}\text { Performan } \\
\text { ce } \\
\text { Measures }\end{array}$ & $\begin{array}{l}\text { Instrumental } \\
\text { ity }\end{array}$ & $\begin{array}{l}\text { Contingen } \\
\text { t Rewards }\end{array}$ & $\begin{array}{c}\text { Motivatio } \\
\mathrm{n}\end{array}$ & & \\
\hline \multicolumn{7}{|c|}{ Female } & & \\
\hline $\begin{array}{l}\text { Correlati } \\
\text { on }\end{array}$ & 0.67 & 0.56 & 0.64 & 0.65 & 0.62 & 0.57 & 0.63 & 0.61 \\
\hline
\end{tabular}


Gender Disparities In Drivers Of Workers Satisfaction

\begin{tabular}{|c|c|c|c|c|c|c|c|c|}
\hline $\begin{array}{l}\text { Coeffici } \\
\text { ent }\end{array}$ & & & & & & & & \\
\hline $\begin{array}{l}\text { Significa } \\
\text { nce (2- } \\
\text { tailed) }\end{array}$ & $<0.001$ & $<0.001$ & $<0.001$ & $<0.001$ & $<0.001$ & $<0.001$ & $<0.001$ & $<0.001$ \\
\hline $\mathrm{N}$ & 104 & 104 & 101 & 103 & 101 & 104 & 100 & 102 \\
\hline \multicolumn{9}{|c|}{ Male } \\
\hline $\begin{array}{l}\text { Correlati } \\
\text { on } \\
\text { Coeffici } \\
\text { ent }\end{array}$ & 0.65 & 0.67 & 0.54 & 0.57 & 0.61 & 0.58 & 0.63 & 0.68 \\
\hline $\begin{array}{l}\text { Significa } \\
\text { nce (2- } \\
\text { tailed) }\end{array}$ & $<0.001$ & $<0.001$ & $<0.001$ & $<0.001$ & $<0.001$ & $<0.001$ & $<0.001$ & $<0.001$ \\
\hline $\mathrm{N}$ & 131 & 125 & 132 & 130 & 131 & 127 & 128 & 132 \\
\hline
\end{tabular}

The results reveal significant positive correlations $(\alpha<0.001)$ between all the eight independent variables and workers satisfaction for both males and females. For the first hypothesis, stability and security was found to be positively correlated with workers satisfaction. For the second hypothesis the study confirms that feedback on performance from superiors is positively correlated workers satisfaction. The study found for the third hypothesis that performance measures are positively correlated with workers satisfaction. Instrumentality was also found to be positively correlated with workers satisfaction in the fourth hypothesis. For the fifth hypothesis there was a positive and significant correlation between contingent rewards and workers satisfaction. There was also a positive and significant correlation between motivation and workers satisfaction in hypothesis six. For hypothesis seven workers control and autonomy was found to have a positive and significant correlation with workers satisfaction. Challenge was found to have a positive and significant correlation with workers satisfaction in hypothesis eight. Eight key drivers of workers satisfaction among print media journalists were tested for both females and males. All drivers were found to be highly significant in positively influencing their satisfaction of sampled print media journalists. However the results indicate no differences between males and females in the eight tested key drivers of workers satisfaction. Workers satisfaction is an affective or emotional response toward various facets of their jobs. It is important because of its implications for job-related variables.

\section{Recommendations and Conclusion}

Several factors and influences in the workplace are responsible for workers job satisfaction. The need therefore arises for organization leadership to foster a culture that gives workers a sense of usefulness, dignity, and value. Supervisors and managers should operationalize corporate culture. They must implement measures that bring about workers satisfaction. They must also be champions for workers to make sure they are remunerated commensurate with performance. The eight key drivers of workers satisfaction namely stability and security; feedback; performance measures; instrumentality; contingent rewards; motivation; control as well as autonomy and challenge all of which were tested and found to be positively correlated with workers job satisfaction for both females and males must be taken into consideration.

Again, workers need to attempt to maximize their satisfaction in the workplace through increased participation in organization goal-setting process to ensure that their duties are challenging and so that have higher levels of satisfaction. They must also be self-motivated and perform their assigned duties to the levels established during the goal-setting process and be more willing to accept constructive criticisms during performance reviews, which will enable them to increase their level of instrumentality to the organization.

Job satisfaction is an important variable to consider when evaluating organization success. Employees' concerns must be met to achieve organization productivity. Job Satisfaction can be indicative of work behaviours and withdrawal behaviours. It can partially mediate the relationship of personality variables and deviant work behaviours. Among work attitudes, job satisfaction is a strong predictor of absenteeism; therefore increasing job satisfaction and organizational commitment are potentially good strategies for reducing absenteeism and turnover intentions for both male and female employees. 


\section{References}

[1]. Clark, A. E. (1997). Satisfaction and Gender: Why are female so happy at work? Labour Economics, 4(4): 341-372.

[2]. Medaiyese, T. Y. (2002) Determinants of Satisfaction of Federal Government Workers. Public Personnel Management, 26(3), 313334.

[3]. Adenekan(2005). Gender Issues and Human Development: The Challenge of the $21^{\text {st }}$ Century Ibadan: Social Sciences and Reproduction

[4]. Health Research Network Distinguished lecturer.12(1): 27-35

[5]. Fields, D., \& Blum, T. C. (1997). Workers satisfaction in work groups with different gender composition. Journal of Organizational

[6]. Behavior, 18, 181-196.

[7]. Pook, L. A., Füstös, J., \& Marian, L. (2003). The impact of gender bias on satisfaction Components of satisfaction and advancement in post-liberation Hungary, Poland, and Romania. Human Systems Management, 22(1): 37-50.

[8]. Oloko, O. (2001) Influence of unplanned versus planned factory locations on workers commitment to industrial employment in Nigeria, Socio-Economic planning science (vol.7) Pergamon Press Great Britain Moser, A. (2010).Doing Gender, Doing Difference: Inequality, Power, and Institutional Change.' New York, NY; Routledge. Giddens, A. (2006). Sociology $5^{\text {th }}$ ed. Polity Press U. K.

[9]. Soetan, F. (2002). "Gender Mainstreaming in the Workplace; An Analysis of the Nigerian Experience" A Paper Presented in a Work Shop. 12-18 United Nations Development Programme (UNDP)[10]

[10]. Deaux M.N. and Enswiller Y. S. (2003) Perceptions of female and men as Entrepreneurs: Evidence for Differential Effects of attributional Augmenting Journal of Applied Psychology, 86 (5) 923-929.

[11]. Locke, E. A (1976) The Nature and causes of Satisfaction in Dunnette, M. D. (ed.). Handbook of Industrial and Organisational Psychology.

[12]. Judge et al. (2001) Organisational Behaviour. New Delhi: Prentice-Hall of India private Ltd. Colbert W. C. and Heller, P.I. (2001) Rethinking Public Pension Reform Initiative. Washington D.C: International Monetary Fund: IMF

[13]. Working Paper 98/6/

[14]. Awe B. J. (2006) Do Female Entrepreneurs Require Different Training? Asian Journal of Small Business,

[15]. Majekodunmi (2008) "Differences In Motivation and Satisfaction Among Female and Male Managers," Human Relations 35:10118.

[16]. Smith J.S, Kendall W. S., and Hulin C. R. (1989) Gender as a Determinant of Small Business Performance: Insight from a British Study.

[17]. Small Business Economics, 8: 463-78.

[18]. Spector P. E. (1997) Satisfaction: Application, Assessment, Causes and Consequence, Sage Publications, London.

[19]. Ogundele, O.J.K (2005). Management and Organisation: Theory and Behaviour. Lagos: Molofin Nominee.

[20]. Kim, J.S. and Cho M.N. (2003) Entrepreneurial Female and Men: Two Different Species? Small Business Economics, 16(3): 167175.

[21]. Mottaz, C. (1986), "Gender Differences in Work Satisfaction, Work-related Rewards and Values and the Determinants of Work Satisfaction," Human Relations 39:359-78.

[22]. Kim, S. (2005). "Gender Differences in the Satisfaction of Public Workers: A Study of Seoul Metropolitan Government, Korea". Journal of Research in Sex and Roles, May 1, 2005.

[23]. Sousa-Poza, A., \& Sousa-Poza, A. A. (2000). Gender differences in satisfaction in Great Britain, 1991- 2000: Permanent or transitory? Applied Economics Letters, 10(11): 691-694.

[24]. Khaleque Y.G., Rahman M.N. (1987) Where the Job Satisfaction of Bank Employees Lies: An Analysis of the Satisfaction Factors in Dhaka City, The Cost and Management Journal of ICMAB, 34(3).

[25]. Sirota, D., \& Mischkind, L. A. (2006). Stop demotivating your workers! Harvard Management Update, 11(1): 3-6.

[26]. Bolt, J. F. (1983). security: Its time has come. Harvard Business Review. 61(6): 115-123.

[27]. Kim, J. S. (1984). Effect of behavior plus outcome goal setting and feedback on workers satisfaction and performance. The Academy of Management Journal, 27(1): 139-149.

[28]. Jawahar, I. M. (2006). Correlates of satisfaction with performance appraisal feedback. Journal of Labor Research, $27(2)$ : $213-236$.

[29]. Walker, O. C., Jr., Churchill, Jr., G. A., \& Ford, N. M. (1977). Motivation and performance in industrial selling: Present knowledge and needed research. Journal of Marketing Research 14(2): 156-168.

[30]. Teas (1981) Teas, R. K. (1981). An empirical test of models of salespersons' expectancy and instrumentality perceptions. Journal of Marketing Research, 18(2): 209-226.

[31]. Michael S. U. (2005) The Impacts of Human Resource Management Practices and Pay Inequality on Workers Satisfaction. Paper Presented at Western Economic Association. $79^{\text {th }}$ Annual Conference Vancouver

[32]. McClelland, D.C. (1965). N Achievement and Entrepreneurship: A longitudinal study. Journal of personality and social psychology, 1(4), 389-392.

[33]. Drucker P.F. (2000). "Management Tasks, Responsibility Practices, Oxford, Butterworth - Heinemann.

[34]. Lawler L., \& Stuttle, J. R. (1983). Corporate profits and workers satisfaction: Must they be in conflict? California Management Review, 14(1): 46.

[35]. Collins F. V. (2006) Exploring the relationship between attitudes towards growth, gender. Journal of Business Venturing, 13(6): 523-542.

[36]. Okafor V.M. (1997) An Examination of Relationship between Affective Reactions, Work Perceptions, Individual Resource Characteristics and Multiple Absence Criteria. Journal of Orgaizational Behaviour, 14, 515-530.

[37]. Kimberly (2003) Gender and Organizational Performance: Determinants of Small Business Survivial and Success. Academy of Management Journal, 34(1): 136-161. 